\title{
Million International Units
}

National Cancer Institute

\section{Source}

National Cancer Institute. Million International Units. NCI Thesaurus. Code C67335.

A unit of biological activity equal to one million international units. 